\title{
Comparative Effectiveness of Self-Instructional Print Media and Conventional Teaching Method on Secondary School Students Achievement in Physics in Osun State
}

\author{
Oluseyi Abraham Olaniyi \\ Department of Educational Technology \\ Faculty of Education, National Open University of Nigeria \\ PMB 80067, Victoria Island, Lagos, Nigeria \\ Tel: 234-803-929-9377 \\ E-mail: emperorseyi@gmail.com \\ Moshood Ayinde Hassan \\ Professor \\ Department of Adult Education, Faculty of Education \\ Adekunle Ajasin University \\ PMB 00I, Akungba-Akoko, Ondo State, Nigeria \\ Tel: 234-803-422-9218 \\ E-mail: ayindeayindeayinde@hotmail.com
}

\begin{abstract}
The current decline in the performance of secondary school students in Physics in the Senior School Certificate Examination (SSCE) has become a major concern for the stakeholders in the field of education. This may perhaps, be partly due to the strict adherence of Physics teachers to the use of conventional teaching method in teaching Physics. This study was therefore carried out with the aim of evaluating the comparative effectiveness of Self-instructional Print Media and the conventional teaching method on secondary school students' achievement in Physics in Osun State. A non-randomised control group pretest-posttest quasi-experimental research design was adopted for the study. Self-Instructional Printed Material in Physics (SIPMP), Lesson Plan in Physics (LPP), Entry Behaviour Test in Physics (EBTP) and Achievement Test in Physics (ATP) were the research instruments used in this study. One hundred and seventy three (I73) SSS II students from six intact classes of six purposively selected secondary schools in Osun State constituted the sample of the study. These students were randomly assigned into the three quasi-experimental groups, namely: Self-instructional Print Media alone (SIPM alone), Self-instructional Print Media with the conventional Teaching Method (SIPM with CTM) and the Conventional Teaching Method alone (CTM alone). The three groups were tested prior to and after their exposure to the experimental treatment. The data collected were analysed to answer the five research questions and test the four hypotheses raised for the study using mean scores, t-test, ANOVA and ANCOVA at 0.05 level of significance. The findings of this study indicated that the three groups were equivalent or homogeneous prior to the application of the experimental treatment. The three groups also recorded significant improvement in their achievement in physics after being exposed to the experimental treatments. However, the students that were exposed to the self-instructional print media (whether independently or conjointly with the conventional teaching method) significantly outshone their counterparts that were taken through the conventional teaching method alone. Based on these findings, secondary school physics teachers were admonished to embrace the use of self-instructional print media to promote effective and efficient teaching and learning of Physics. They were also encouraged not to completely abandon the use of the conventional teaching method.
\end{abstract}

Keywords: Self- Instructional Print Media (SIM), Conventional Teaching Method (CTM), Achievement, Effectiveness, Programmed Instruction, Reinforcement, Operant Conditioning.

\section{Introduction}

\section{I.I Background to the Study}

Science is any system of knowledge that is concerned with the physical world and its phenomena and that entails unbiased observation and systematic experimentation (Encyclopedia Britannica, 20I4). Besides, Ogunniyi, (I998) defines science as an attempt by human beings to organize their experience about nature into meaningful system of explanation. Emovon, (I995) sees science as a body of knowledge which is acquired through observation and systematic experimentation.

Combining these definitions, one can define science as a field of study in which human beings seek to understand and explain materials and forces of nature through systematic and objective observation and experimentation. It is systematic because 
it consists of various stages that are mutually independent and functionally integrated in such a way that a mistake or fault noticed at any of the stages will affect the overall outcome of the process. It is also objective because the outcome is determined by the empirical evidence gathered through the collection and analysis of data and not by the emotion of the observer or experimenter. Contemporary science is typically divided into the natural sciences (Physics, Chemistry, Biology and Earth science) which study the material world and social sciences which study people and the societies. (Wikipedia, 2016).

There are several methods of teaching sciences within the conventional teaching method, these includes: expository or teacher talk and chalk method, problem- solving method, project method, group work method, discussion method etc. These methods are collectively referred to as conventional teaching methods because, they require the physical presence of a teacher before they can be used. Effective teaching of science does not only depends on the teacher's knowledge of the methods but also on his/her ability to use the appropriate method or combination of methods. Asoko, (2000) opines that in all countries, teachers are the key to realizing the curriculum aims and the quality of science education which students receive rests ultimately on them.

Physics is a core subject in the field of natural science. The teaching and learning of Physics is important to the students because, Physics forms the nucleus of many courses in the field of science and technology, these include: electrical engineering, mechanical engineering, material science and engineering, computer science and engineering, civil engineering etc. without a credit pass in Physics in Senior Secondary Certificate Examination (SSCE), a student cannot be admitted into any higher institution to study any of the listed courses.

One of the broad goals of secondary education in Nigeria is to prepare the individual for higher education (National Policy on Education, 2004) and to actualize this goal; teaching and learning of Physics must be given adequate focus and attention. This is because teaching and learning of Physics is a complex process that requires more than the singular effort of the teacher through the conventional classroom teaching. Learners are also expected to complement the effort of their teachers by exhibiting conscious and deliberate individual effort and commitment towards the learning of Physics. According to Jadav, (2004), subjects like Physics and Mathematics require a lot of imagination, self-thinking and practicing problem solving. Gaining conceptual understanding of Physics is difficult for many students. There are limit to what can be done in the class to help students learn Physics in such a manner. Doing more require individualized instruction and productive out-of-class effort on the part of the students?

In view of the importance of science to human development and the role Physics is playing in preparing students for higher education, one is justified to investigate the means by which the subject can be improved upon. Consequently this study focusses on how self- instructional print media can be used to improve secondary school students' performance in Physics in Osun state. The study is entitled: comparative effectiveness of self-instructional print media and conventional teaching method on secondary school students' achievement in Physics in Osun state.

\section{Statement of the Problem}

The current decline in the performance of students in Physics in the Senior School Certificate Examination (SSCE) has become a major concern for the stakeholders in the field of education. This may perhaps, be partly due to the strict adherence of Physics teachers to the use of conventional teaching method in teaching Physics. The use of self-instructional media to facilitate learning of Physics has not be given adequate consideration by the Physics teachers. Consequently, this study entitled: Comparative Effectiveness of Self-instructional Print Media and Conventional Teaching Method on Secondary School Students' Achievement in Physics in Osun State is embarked upon.

\section{Purpose of the Study}

- Find out the effectiveness of self- instructional print media on students' achievement in Physics;

- Ascertain the effectiveness of conventional teaching method on students' achievement in Physics;

- Find out the effectiveness of self- instructional print media conjointly used with the conventional teaching method on students' achievement in Physics;

- Determine which of the self- instructional print media and conventional teaching method contributes more to the students' achievement in Physics; and

- Verify which among the self- instructional print media used alone, self- instructional print media used with the conventional teaching method and conventional teaching method alone contributes most to the students' achievement in Physics.

\section{Theoretical Framework}

This study is built on behaviourism theory specifically Skinner's Operant or instrumental conditioning theory and Thorndike theory of connectionism. Self-instructional media are grounded on skinner's operant conditioning theory (Sharma, n.d.). This theory believes that learning is a product of outcome or consequence of response given to a stimulus. That is, an individual is likely to repeat an action or behaviour if the outcome or consequence of the action or behaviour is rewarding, pleasant or 
reinforcing. B. F. Skinner coined the term operant conditioning; it means roughly changing of behaviour by the use of reinforcement which is given after the desired response (McLeod, 2005).

According to Skinner (1938), behavioural responses become connected to environmental stimuli largely as a result of what happens after the response occurs. A learner will possibly repeat an action that led to the solution to a problem when confronted with a similar problem in the future (NOUN, 2009). Operant conditioning is a method of learning that takes place through rewarding a certain behaviour or withholding reward for an undesirable behaviour. Thus an association is made between the behaviour and its consequence (Christopher, 2016). For instance, a student who is given an applause on the assembly ground for being punctual in the school is likely to continue to be punctual while the one given a public jeering for coming late to school perpetually is likely to change for better.

Skinner identifies three types of responses:

- Neutral Operants: Responses that do not alter the probability of a behaviour being repeated.

- Reinforcers: Responses that increase the probability of a behaviour being repeated.

- Punishers: Responses that decrease the probability of a behaviour being repeated (McLeod, 20I5, Christopher, 2016).

There are two main components of operant conditioning; reinforcement and punishment (Peggy, 20I3). These components are summarized in the figure below.

Figure I: Operant Conditioning Theory.

\section{Operant Conditioning}

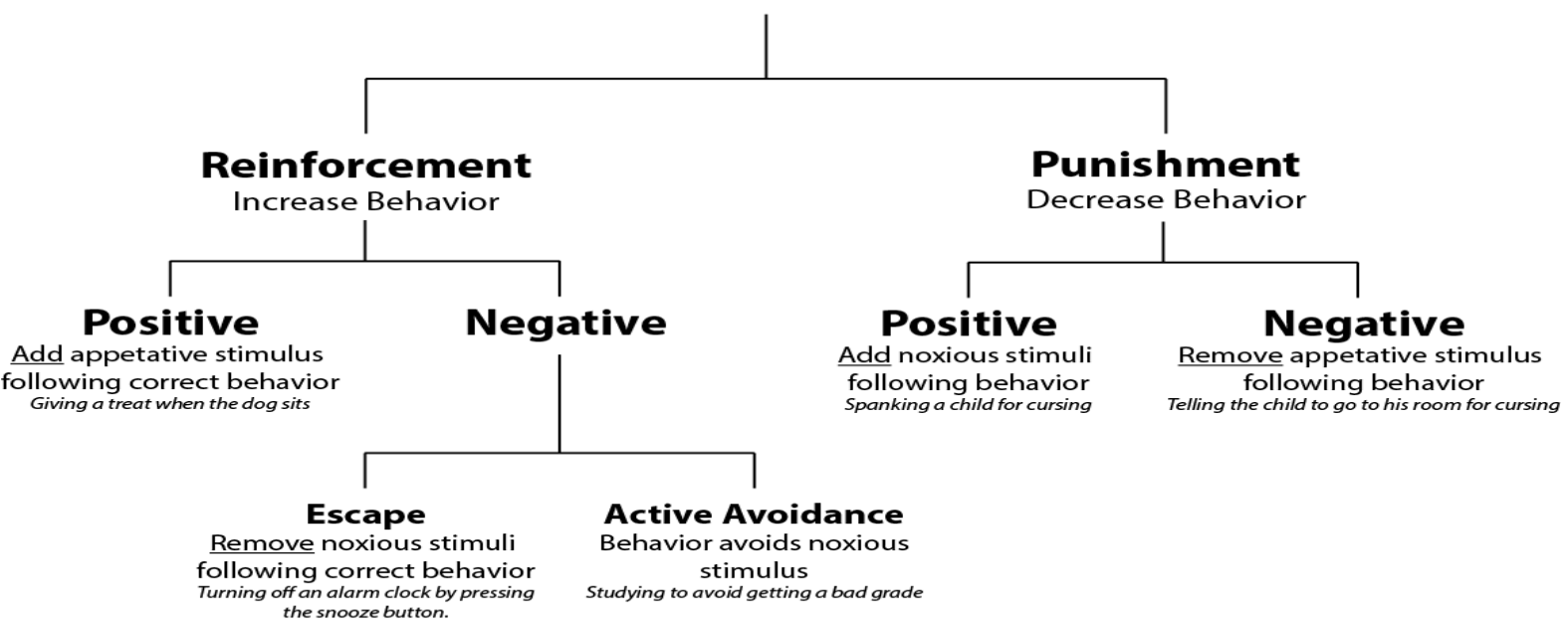

Postive presence of a stimulus

Negative absense of a stimulus

Reinforcement increases behavior

Punishment decreases behavior

Escape removes a stimulus

Avoidance prevents a stimulus

Source: Curtis N. (2016). Wikipedia. htpps://en.m.wikipedia.org/wiki/operant-conditioning

Reinforcement is used to strengthen behaviour. A reinforcer is anything that strengthens the desired response (Richard, 20I5). According to Schultz (2006), reinforcement is responsible for response strengthening - increasing the rate of responding or making responses more likely to occur. A reinforcer (reinforcing stimulus) is any stimulus or event following a response that lead to the response strengthening.

Punishment on the other hand is used to weaken behaviour. Skinner (1953) opines that punishment often brings about responses that are incompatible with punished behaviour and that are strong enough to suppress it. Punishment decreases the future likelihood of responding to a stimulus (Dale, 2012). Positive punishment is the application of aversive stimulus to weaken an incorrect or unacceptable behaviour (Reed and Lovett, 2008). It is the addition of something which causes the decrease in the behaviour that was displayed (Sincero, 20I I). For instance, a student may be caned for coming late to the school or for lack of concentration during the lesson. Negative reinforcement is the withdrawal of desired stimulus/event after a 
particular undesired behaviour is exhibited, resulting in the behaviour happening less in the future (Sadowski, 20I2). It is the removal of something which is favourable in order to decrease the likelihood of the behaviour to reoccur (Sincero, 20II). A good example of this is when a student is temporarily suspended from his/her post for exhibiting bad manners. The reinforcement and punishment processes is summarized in the figure below.

Figure 2: Reinforcement and Punishment Process

\begin{tabular}{|c|c|c|c|}
\hline $\begin{array}{l}\text { Discriminative } \\
\text { Stimulus }\left(\mathrm{S}^{\mathrm{D}}\right)\end{array}$ & Response (R) & $\begin{array}{c}\text { Reinforcing } \\
\text { (Punishing) Stimulus } \\
\left(\mathrm{S}^{\mathrm{R}}\right)\end{array}$ & $\begin{array}{c}\text { Type of } \\
\text { Reinforcement/Punishment }\end{array}$ \\
\hline $\begin{array}{l}\text { T gives independent } \\
\text { study time }\end{array}$ & L studies & $\begin{array}{l}\text { T praises L for good } \\
\text { work }\end{array}$ & $\begin{array}{l}\text { Positive Reinforcement } \\
\text { (Present Positive Reinforcer) }\end{array}$ \\
\hline $\begin{array}{l}\text { T gives independent } \\
\text { study time }\end{array}$ & L studies & $\begin{array}{l}\text { T says } L \text { does not } \\
\text { have to do } \\
\text { homework. }\end{array}$ & $\begin{array}{l}\text { Negative Reinforcement } \\
\text { (Remove Negative } \\
\text { Reinforcer) }\end{array}$ \\
\hline $\begin{array}{l}\text { T gives independent } \\
\text { study time }\end{array}$ & L wastes time & T gives homework & $\begin{array}{l}\text { Positive Punishment } \\
\text { (Present Negative } \\
\text { Reinforcer) }\end{array}$ \\
\hline $\begin{array}{l}\text { T gives independent } \\
\text { study time }\end{array}$ & L wastes time & $\begin{array}{l}\text { T says } L \text { will miss free } \\
\text { meal }\end{array}$ & $\begin{array}{l}\text { Negative Punishment } \\
\text { (Remove Positive } \\
\text { Reinforcer) }\end{array}$ \\
\hline
\end{tabular}

${ }^{*} T$ refers to the teacher and $L$ refers to the learner.

Source: Adopted from Dale H.S. (2012), Learning Theories, An Educational Perspective,Boston; Allyn and Bacon. Page 9I.

In self-instructional media, the instructional content (subject matter) is the stimulus while educational media are the vehicles carrying the stimulus, (Rowntree, 1974). These media can be in printed or electronic form. They are information carriers employed in instruction (Agun and Imogie, 1988). In a self-Instructional Print Media, this instructional content is usually broken into smaller chunks or units that are sequentially and logically arranged from known, familiar and simple facts to new and more complex facts and principles using frames with each frame containing a bit (NTI, 2007). A learner is expected to understand a unit completely before moving to the next. This is in accordance with the information processing theory formulated by Piaget in 1926 and developed by Anderson in I977 which established the point that when what is learnt is clearly categorized, organized into units and sequenced, then, it is easy to store it and retrieve it from the long term memory, (Adanu, Eskey and Onu, 20I2).

The response is the expected learning outcomes stated in behavioural terms, such as: the ability to write, list, explain, solve a problem etc. the extent to which these expected responses has been actualized by a learner is usually tested through the administration of criterion-referenced test at the end of each unit, thus helping the learner to participate actively in the learning process. The learners with correct responses are reinforced with the use of complementary comments such as Excellent, Bravo, while hints to correct responses are provided for those with incorrect responses. The programmed instruction (Self-instructional Media) used for this study is designed based on this theory.

Thorndike theory of connectionism is the major theory upon which conventional teaching method is based. According to Thorndike (190I), the fundamental of learning is the association between sense impression (stimulus) and impulses to action (response). These association or connection becomes strengthened or weakened by the nature and frequency of the stimulusresponse pairing (Richard, 20I5). He postulated that learning in an organism involves the act of selecting the most appropriate responses and associating them with the specific problems or stimuli (NOUN, 2009). Learning is the connection of a certain act 
with a certain situation and a resultant pleasure (Thorndike, 1898). This simply means for learning to occur a learner must see the connection or association between the instructional content (stimulus) and the expected learning outcomes (responses). The basic unit used for describing behaviour is stimulus-response (SR) connection and all learning involves the formation of new stimulus- response connections (Obi, 200I). An educated adult possesses millions of stimulus-response connections (Shunk, 2012).

Thorndike emphasised motivation and reinforcement as two factors that are necessary for learning to occur. The cat must be hungry (motivation) in order to see the reason to open the box so as to get the food and it must also satisfy his hunger with the food (reinforcement) after opening the box. (Obi, 200I). This is revealed in the three laws of learning developed by Thorndike: Law of readiness, law of exercise and law of effect. Law of readiness was intended to account for the motivational aspect of learning (Weibell, 20I I). It suggests that a teacher can only instruct a student if that student is willing to be educated, when a student does not show any sign of readiness, a teacher should provide instruction that will help the student develop (Christopher, 2016). Law of exercise states that connections become strenghtened with practice and weakened when practice is discontinued (Richard, 2015). Connections grow stronger when used and grow weaker when not used (Weibell, 20I I). Law of effect states that if an event was followed by a reinforcing stimulus, then the connection was strenghtened. If, however, an effect was followed by a punishing stimulus, then, the connection was weakened (David, 1998).

This theory is germane to this study because it empowers the teacher to appreciate the reason why he/she should employ an incorporated use of various conventional teaching methods and educational media such as: chalkboard, poster, chart, graphics, models,specimens, dioramas, instructional radio and television, etc to present instructional content (subject matter) in a way that learners will be sufficiently motivated to see the connection between the instructional content (stimulus) and the expected learning outcomes (responses). It will also guide the teacher to see the needs to reward the students who give correct responses to the exercise given at the evaluation stage of the lesson with complementary remarks such as: Excellent, Bravo, Very good, etc and good grades which may be included in the continuous assessment that will eventually form a significant part of their final scores in the subject, while correction and guidance should be provided for the students with incorrect responses.

The key assumptions of the two behaviouristic theories reviewed in this study that are important to both selfinstructional media and conventional classroom teaching are: learning occurs by accumulating atomized bits of knowledge, learning is sequential and hierarchical, transfer is limited to situations with a high degree of similarity, test should be used frequently to ensure mastery before proceeding to the next objective. Test are the direct instantiation of learning goals and motivation is externally determined and should be as positive as possible (Lorrie, 2000, Greeno, Collins and Resnick, I996, Shepart, 199I, Shulman and Quinlan, 1996).

\section{Literature Review}

Sushmita (2005) defines Self-instructional media (SIM) as written elaboration of a set of learning opportunity organised around a well-defined theme/topic in such a way that, it (is): a self contained instruction unit to be used in a self-learning situation, guarantees self-sufficiency (and) structured in such a way that it helps the learner to find their way into the text and to find their way through the text. It is a learner-oriented instruction in which learning takes place without requiring the physical presence of a teacher. It is based on the principles of programmed learning which in turn are founded on the concept of operant conditioning given by skinnner (Sharma, 20II). These materials enable students to learn at their own convenience in terms of pace, rate of assimilation as well as place and time of use. They also cater for the individual differences in learners (NOUN, 2009). A self-instructional material therefore performs the function of a live teacher. According to Rowntree (I986), the selfinstructional material must carry out all functions a teacher would carry out in the conventional situation, guiding, motivating, intriguing, expounding, explaining, provoking, reminding, asking questions, discussing alternative answers, appraising each learner's progress, giving appropriate remedial or enrichment help and so on.

Jadav (20I4) opines that all underlying assumption in this method of instruction (SIM) is that human-beings learn many things through their own effort. Every individual has a natural desire to learn on his/her own. Another assumption is that, every individual is unique; he/she learn according to his or her ability. Sansanwal (I978) identifies some of the characteristics of self-instructional media to include: self-paced, flexible, auto-instructional, economical in time and effort, more interesting and exciting and may be developed within the available resources. Lockwood (I997) also lists attributes of SIM to include: individual learning, self-paced learning, private learning, available at any time, available at any place, available at any number, standardised content, expert content, updatable content, structured teaching, active learning, frequent feedback, explicit objectives and individualised tutoring. The cycle of a self-instructional material are usually arranged hierarchically as shown in the figure below. 
Figure 3: Cycle of a Self-instructinal Material.

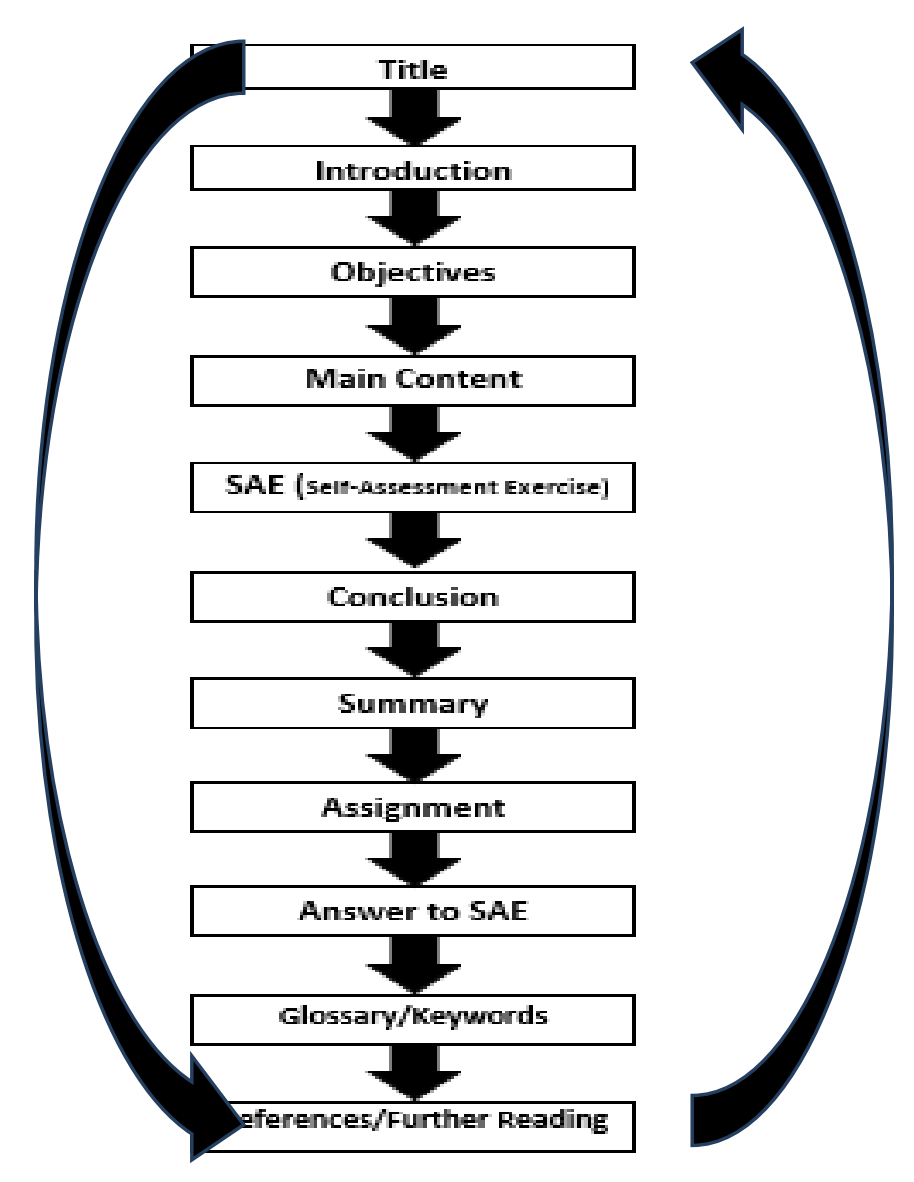

Source: The Authors

The two common types of self-instructional media are: Programmed Instruction (PI) and Computer Assisted Instruction (CAI) (NTI, 2007)

\section{I. Role of Teacher in the Use of Self-Instructional Media}

The development of self-instructional media has enabled the teachers' job to evolve from then usual conventional dissemination of information in the classroom to that of an organiser, manager, designer, producer and facilitator of instruction (LaboPopoola, 2005). According to Charp (I965) the teachers' time will be used in leading group discussions, in working with students individually and in small groups using laboratory work where applicable. The teacher should do away with the baseless fear that the use of self-learning material will relegate their position to that of a passive actor and consequently eliminate them from teaching service. Kersh (1965) opines that it is frequently said that the classroom teacher will never be replaced by programmes of sel-instruction. Rather, he will be freed to guide the learning of his students in a way that only human being can.

Relieved from pure informative tasks, he (the teacher) could dedicate himself to the processing of this information: he would guide the students in the multitude of diversified documents, would help him to make relevant choices and to make the most of them through efficient working, would not hesitate, if necessary to send him back to the resources from cultural, economic or social field, because, he should not fear to lose his power, convinced that he would barter the distribution role for the mediator one, to become guarantor of assimilation and no more spectator of incomprehension (Meirieu, 1989). Teachers should therefore embrace the opportunity provided by self-instructional media in changing their role to that of a facilitator who helps and guides the learner in dealing with the difficulties and misconceptions encountered in the use of self- instructional media. 


\subsection{Conventional Teaching Method}

Suman and Neelam (2013) define conventional teaching as the most common method of teaching used by the teachers for carrying out the teaching learning process in the classroom situation. In this method, the teacher talks more or less continuously to deliver the facts and ideas worth remembering. It is conceived as the transmission of 'knowledge' or 'information' from the teacher to the students. The teacher in this instance prepare for the active role in the classroom (provide and guide) and students are able to demonstrate their knowledge by filling in the blank or choosing the appropriate alternatives on the test. (Marting and Engeno,I992). The distinctive feature of conventional teaching method is that, the teacher is solely responsible for making sure that the learners understand what they are being taught. Abida and Muhammad (2012) orate that the traditional classroom often looks like a one person show with a largely uninvolved learner. This implies that, it is one of the autocratic teaching strategies (Suman and Neelam, 2013). A teacher dominated strategy of teaching where the teacher dishes out learning content and the learners merely struggle to learn them (Deborah, 1997).

Conventional classroom learning is acquired passively rather than actively, it is the product of observation than exploration, (Bertrand, 1946). Students are expected to blindly accept the information they are given without questioning the instructor (Stofflett, 1998). Conventional teaching method does not cater for the individual differences in learners. According to Lord (1999), this teacher-centered method of teaching assumes that all students have the same level of background knowledge in the subject matter and are able to absorb the material at the same pace. Soyemi, Ogunyinka and Soyemi (n.d.) state that conventional learning typically takes place in an identifiable classroom space, usually in a school or in an institution dedicated to learning. Soyemi et al. (n.d.) identify the specific features of a conventional classroom to include: A set of chairs and desks arranged in rows and columns, an instructor/teacher who delivers information to students, a number of students/ learners who are all physically present in the classroom and regularly meet at a specific time, and students participation in lecture and discussion.

\subsection{The Nature of Physics}

Omosewo (1999) defines Physics as the branch of science that deals with energy and matter, and their interactions. Nelkon (I997) defines physics as a science concerned with the behaviour of matter. More broadly, it is the general analysis of nature, conducted in order to understannd how the universe behaves Luarie (2016). Nelkon (1997) identifies some of the branches of Physics as electricity, optics, heat,sound, properties of matter and atomic theory. Laurie (2016) reveals further that physics deals with the structure of matter and the interraction between fundamental constituents of the observable universe. In the broadest sense, Physics (from Greek word Physikos) is concerned with all aspect of nature on both the macroscopic and submicroscopic levels. Its laws are typically expressed with economy and precision in the language of mathematics. Physics is of the oldest academic discipline, perhaps the oldest through its inclusion of astronomy. Physics intercepts with many inter-discipline areas of research such as: biopysics, quantum chemistry, etc and the boundaries of Physics are not rigidly defined (Encyclopedia Britannica). Laurie (2016) confirms this when he writes:

'Physics plays an important role in all natural sciences, ... and all such fields have branches in which Physical laws and measurement receive special emphasis, bearing such names as, astrophysics, geophysics, biophysics and even psychophysics'.

Physics also makes significant contribution through advances in new technologies that arise from theoretical breakthrough. Many useful inventions and machines have been produced (through researches in physics). Radar control at London and other large airport; computers in banks; colour television transmission by British and other national radio corporations; high-power microscope for use in laboratories; and anti-skid tyres for cars, have all developed from researches in physics (Nelkon, I977).

\subsection{Physics in the Curriculum in Nigeria}

The establishment of CMS Grammar School, Lagos, (The first grammar school in Nigeria) in I859 pioneered the introduction of science subjects like arithemetics, algebra, geometry and physiology into the school curriculum in Nigeria (Omolewa, I977; Adeyemo, 2010). A number of secondary and teacher trianing institutions were founded between I859 and I929 and their curriculum were science friendly. These science subjects include: astronomy, chemistry, Physiology, geology and botany, (Adeyemo, 2010). However, science teaching and learning suffered in the hands of teachers and students, entry performance at the external examinations were very poor (Omolewa, 1997).

The visit of Phelph-Stroke funded education commision to West Africa in 1920 led to the discovery of deficient state of science education and a strong recommendation was made for the inclusion of science subjects into the curruculum of all secondary schools in West Africa (Adeyemo, 2010). Curriculum development conferences and workshop were held in Nigeria between 1969 and 1975 resulting in the production of science curriculum materials for both primary and secondary levels (Ivowi, 1982, Adeyemo, 2003). Physics was one of the science subjects introduced into the science curriculum. The general objectives of Physics curriculum as contained in the curriculum document of 1985 by Federal Ministry of Education (FME) and revised in 1998 are to:

- Provide basic literacy in Physics for functional living in the society;

- Stimulate and enhance creativity; 
- Acquire essential skills and attitudes as a preparation for technological application of Physics; and

- Acquire basic concepts and principles of Physics as preparation for further studies.

\subsection{Reasons for Studying Physics}

The important of Physics is recognized through out the educational system. Physics is compulsory for all science students in secondary school and for those who want to study engineering and technological related courses in higher institution. According to (Ajayi, 2013), the type of science taught in schools and the dept covered in Physics curriculum in secondary school most often determines the kind of scientists, technologists, engineers and doctors produced in a society. The importance of physics cannot be over stressed as it forms the basis for technological advancement of any nation. Its study can lead to several scientific fields and profession such as engineering, manufacturing, mining and construction industries (Omosewo, I999).

\subsection{Problem Associated with the Teaching of Physics}

The experience of the author of this study in teaching Physics both in private and public schools over a period of five years made him realised that the main problem of students in learning physics is not in their inability to understand the concepts, laws and principles being taught. Rather, the problem, perhaps, lies in their inability to use the concepts, laws and principles to solve the basic problems associated with them. The problem, therefore, has to do with application, rather than understanding. However, this major problem is a manifestation of several challenges that are associated with the teaching of physics.

Jegede and Adedayo (2013) identify some of the problems of physics education in Nigeria as curriculum content, teaching method, teachers' quality, negative attitude of students towards physics, students' ignorance of the relationship between physics and the environment and teaching materials. Adeyemo (2010) lists problem of implementation of Physics curriculum as: interface between physics and mathematics (that is, physics cannot exits without mathematics), lack of modern and adequate laboratory equipment, unavailability of competent teacher, time limitation (that is, teaching of virtually all the topics in Physics requires more time than that allocated on the time table) and inadequate curriculum. According to Boyo (as cited by Omosewo, 2012) the problems associated with the studying of Physics in Lagos, Nigeria are: non-availability of facilities for teaching, lack of classroom, textbooks, journals and overpopulation. Two problems that featured prominently in all the problems identified by the cited schorlars are: the problems of paucity of competent teachers and good textbook. The focus of this study is to find out how self-instructional material (print) can be used to solve these problems.

\section{Methodology}

The design employed in this study is a non-randomized control group pretest-posttest quasi-experimental research design for the main purpose of comparing the effectiveness of Self-instructional Print Media (SIPM) used alone, Self-instructional Print Media conjointly used with the Conventional Teaching Method (SIPM with CTM) and Conventional Teaching Method (CTM) used alone, on the Senior Secondary School year two (SSS II) students' achievements in Physics in Osun State. It is nonrandomized because, intact classes were used and the researcher has no control over the selection of students (subjects) into their respective classes (groups). This was done with the aim of ensuring that the study is conducted smoothly without jeopardizing the normal school activities. The three experimental groups used in this study are represented thus:

$$
\begin{array}{ll}
\text { Group I (SIPM alone) } & \text { E: } \mathrm{X}_{0}: \mathrm{X}_{1}: \mathrm{X}_{4} \\
\text { Group } 2 \text { (SIPM with CTM) } & \text { E: } \mathrm{X}_{0}: \mathrm{X}_{2}: \mathrm{X}_{4} \\
\text { Group } 3 \text { (CTM alone) } & \text { E: } \mathrm{X}_{0}: \mathrm{X}_{3}: \mathrm{X}_{4}
\end{array}
$$

Where: $\mathrm{E}=$ Experimental Group, $\mathrm{X}_{0}=$ Pre-test, $\mathrm{X}_{\mathrm{I}}=$ Treatment I, $\mathrm{X}_{2}=$ Treatment $2 \mathrm{X}_{3}=$ Treatment 3, and $\mathrm{X}_{4}=$ Post-test.

\section{I Population}

This study is targeted at all Senior Secondary School year two (SSS II) students of Osun State, Nigeria.

\subsection{Sample and Sampling Procedure}

The sample for this study is made up of I73 SSS II students in six intact classes from six schools that were purposively selected based on the following predetermined conditions: availability of all the students for the three contact sessions, that is, pre-test, treatment and post-test sessions, readiness of the schools' management to allow the researcher to conduct the study in their schools, readiness of their Physics teacher to help the researcher during the contact sessions, especially during the experimental treatment and ability of the students to properly and maturely handle the Self-instructional material in order to prevent loss and defacement. The six purposively selected schools were randomly assigned into the groups as shown in the table below. 
Table I: Distribution of Participants Based on Schools Selected for the Study

\begin{tabular}{|l|l|c|c|}
\hline \multicolumn{1}{|c|}{ Group } & \multicolumn{1}{|c|}{ School } & $\begin{array}{c}\text { Number } \\
\text { of } \\
\text { Students }\end{array}$ & $\begin{array}{c}\text { Local } \\
\text { Government }\end{array}$ \\
\hline Experimental 1 & Gray's International School, Ede. & 26 & Ede North \\
& Christ Redeemer Model Schoo1, Osogbo & 22 & Osogbo \\
\hline Experimental 2 & Good Tiding Standard Collegiate, Osogbo. & 30 & Osogbo \\
& Good Tiding Standard Collegiate, Ofatedo & 33 & Egbedore \\
\hline \multirow{2}{*}{ Experimental 3 } & Ataoja School of Science Osogbo. & 32 & Osogbo \\
& Ibikunle Lawal School, Ile-Ife & 30 & Ife Central \\
\hline
\end{tabular}

Source: Research Data, September, 2016.

\subsection{Instrument for Data Collection}

Four research instruments were deployed to collect data for this study. These are: Entry Behaviour Test in Physics (ETBP); Achievement Test in Physics (ATP); Self-instructional Printed Material in Physics (SIPMP); and a Lesson Plan in Physics (LPP). These instruments were developed by the researcher. The Entry Behaviour Test in Physics is a 20-item multiple choice objective test with four options developed to measure the input competencies of the subjects in the topic planned to be taught. It contains criterion-referenced test items developed in reference to the learning outcomes that the researcher is expecting the subjects to be able to demonstrate after the treatments. The mean scores of the participants in the three groups used for this study was compared to ascertain the equivalence of the groups prior to the commencement of the treatment

The Achievement Test in Physics (ATP) is also a 20-item multiple choice objective test with four options which contains the same items as the EBTP but arranged differently. This is done to prevent the students from transferring their responses in EBTP directly to the ATP. The students were measured on four of the six levels in the Bloom's cognitive domain, namely: Knowledge, comprehension, application and analysis.

The Self-instructional Printed Material in Physics (SIPMP) is a unit of instruction on the topic 'Equations of Uniformly Accelerated Linear Motion' chosen from the Osun State unified scheme of work for senior secondary schools. The topic is slated for the second week of the first term the senior secondary school year two academic season. The material is designed to 'teach' the students on its own without any assistance from their teachers. The Lesson Plan in Physics (LPP) is a sequential and logical outline of the activities that the teacher is expected to carry out during the lesson in order to ensure effective and efficient attainment of instructional goals. The lesson plan was written for the same topic treated in the selfinstructional printed material using the same examples. This is to ensure that the subjects in the three experimental groups were exposed to the same content with the only difference being the teaching and learning methods.

\subsection{Validity of the Instrument}

Face validity and content validity were the forms of validation conducted for the instruments.

\subsection{Face Validity}

The Entry Behaviour Test in Physics was given to four randomly selected Physics teacher in Osun State secondary school to check the structure, language and the relevance of each item to the lesson topic. Their suggestions, guidance and constructive criticisms were adapted to effect necessary corrections, rejections and acceptance of the items.

\subsubsection{Content Validity}

The psychometric analysis of the items that made up the EBTP and ATP was carried out to ascertain the difficulty indices and discriminative indices of each item that made up the test. A 30-item test was administered to a group of 28 SSS II students of a school within the area of the study but which is not selected for the experimental treatments. The scores of the students were arranged hierarchically from the highest to the least and the upper and lower one-third (33\%) were selected for difficulty and discrimination indices analyses. The items with the difficulty indices between +0.3 and +0.85 and discrimination indices from +4.0 and above were eventually selected, resulting into the dropping of 10 non-viable items. This confirms the content validity of the instrument. 


\subsubsection{Reliability of the Instrument}

Fifty two students in an intact class were used to conduct the reliability test for Entry Behaviour Test in Physics (EBTP) while forty five students in another intact class were used to conduct the same test for Achievement Test in Physics (ATP). The tests were first administered to the students and their scores were recorded. After four weeks the same tests were administered to the same set of students and their scores were also recorded. The correlation coefficients of the two set of scores for each group of the students were calculated using Spearman-Brown Rank-Order correlation coefficient technique. The values of $r=0.82$ was obtained for EBTP while $r=0.85$ was obtained for ATP. This confirmed that the test instruments were reliable.

\subsubsection{Variables of the Study}

The variable used in this study was grouped into three as follows:

- One categorical independent variable: This refers to the three treatment conditions, namely: the Self-instructional Print Media (SIPM), Self-instructional Print Media with Conventional teaching method (SIPM with CTM) and the Conventional Teaching Method (CTM).

- One dependent variable: This refers to the students' achievement in Physics.

- Intervening/Confounding variables: These include: students' intellectual abilities, rates of assimilation, preferred learning styles, bias due to non-randomized allocation of subjects into the three experimental groups, etc.

\section{Data and Result}

\section{Hypotheses Testing}

Three hypotheses were raised and tested for this study and the outcome of the test is presented below.

\section{Hypothesis One}

Hor: There is no significant difference at 0.05 level of significance among the means of the entry behaviour scores of the students that were exposed to self- instructional print media alone (ExI), self-instructional print media conjointly used with the conventional teaching method (Ex2) and those that were taught through the conventional teaching method alone (Ex3).

Hor: There is no significant difference at 0.05 level of significance among the means of the entry behaviour scores of the students that were exposed to self- instructional print media alone (ExI), self-instructional print media conjointly used with the conventional teaching method (Ex2) and those that were taught through the conventional teaching method alone (Ex3).

Table 2: ANOVA of Entry Behaviour Test in Physics

\begin{tabular}{|c|c|c|c|c|c|}
\hline & Sum of Squares & $\mathrm{df}$ & Mean Square & $\mathrm{F}$ & Sig. \\
\hline Between Groups & II.839 & 2 & 5.920 & I.I56 & .317 \\
\hline Within Groups & 870.392 & $\mathrm{I70}$ & 5.120 & & \\
\hline Total & $882.23 \mathrm{I}$ & $\mathrm{I} 72$ & & & \\
\hline
\end{tabular}

Source: Research Data, September, 2016.

According to table $2, \mathrm{p}=0.317$ and this value is greater than 0.05 level of significance. This means that there was no significant difference in the entry behaviour of the students in the three groups. The null hypothesis was therefore accepted. This implies that the three groups were equivalent prior to the commencement of the experimental treatment.

\section{Hypothesis Two}

$\mathrm{H}_{02:}$ There is no significant difference at 0.05 level of significance between the means of the achievement scores of the students that were exposed to self- instructional print media (ExI) and those that were taught through the conventional teaching method (Ex3).

$\mathrm{H}_{12:}$ There is a significant difference at 0.05 level of significance between the means of the achievement scores of the students that were exposed to self- instructional print media (ExI) and those that were taught through the conventional teaching method (Ex3). 
Table 3: T-test of SIPM and CTM on their ATP

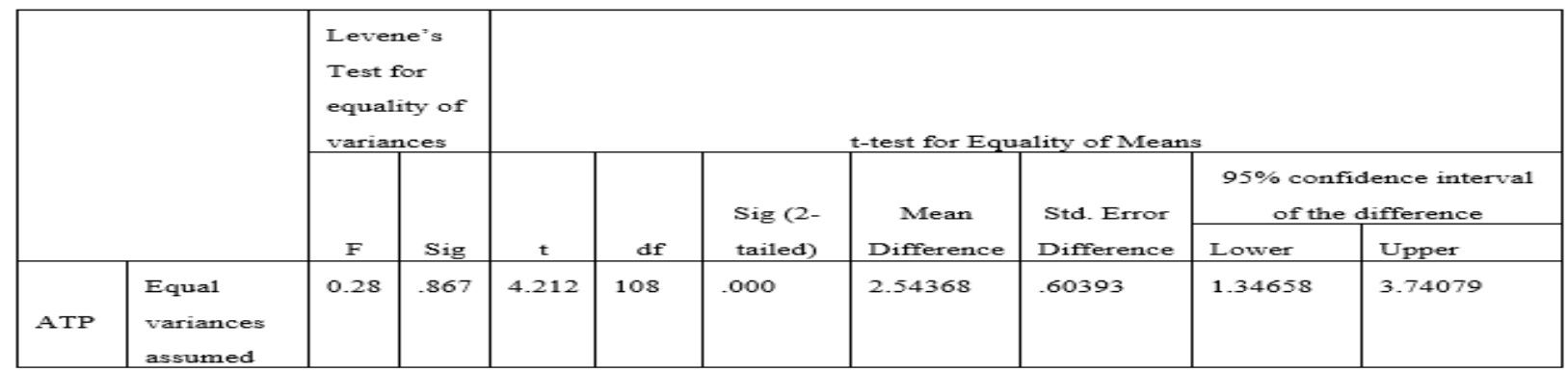

Source: Research Data, September, 2016.

The result of the t-test presented in the table 3 indicates that the $\mathbf{S i g}$ (2-tailed) value is 0.000 and this value is less than the 0.05 level of significance, hence, there was a statistically significant difference between the means of the achievement scores of the students' that were exposed to the Self-instructional Print Media (SIPM) and those that were taught through the Conventional teaching method. The null hypothesis ( $\left.\mathrm{H}_{\mathrm{II}}\right)$ was rejected and the alternative hypothesis $\left(\mathrm{H}_{\mathrm{II}}\right)$ was accepted instead.

\section{Hypothesis Three}

H04: There is no significant difference at 0.05 level of significance among the means of the achievement scores of the students that were exposed to the self- instructional print media alone (ExI), self-instructional print media conjointly used with the conventional teaching method (Ex2) and those that were taught through conventional teaching method alone(Ex3).

Hi4: There is significant difference at 0.05 level of significance among the means of the achievement scores of the students that were exposed to the self- instructional print media alone (ExI), self-instructional print media conjointly used with the conventional teaching method (Ex2) and those that were taught through conventional teaching method alone(Ex3).

\begin{tabular}{lllllll}
\hline $\begin{array}{l}\text { Table 4: ANCOVA of the Three Experimental Groups } \\
\text { Source }\end{array}$ & Type III Sum of Squares & df & Mean Square & F & Sig. & $\begin{array}{l}\text { Partial Eta } \\
\text { Squared }\end{array}$ \\
\hline Corrected Model & $568.039^{a}$ & 3 & 189.346 & 20.661 & .000 & .268 \\
\hline Intercept & 788.620 & I & 788.620 & 86.053 & .000 & .337 \\
\hline EBTP & 358.876 & I & 358.876 & 39.160 & .000 & .188 \\
\hline Independent variable & 172.039 & 2 & 86.020 & 9.386 & .000 & .100 \\
\hline Error & 1548.782 & I69 & 9.164 & & & \\
\hline Total & 33095.000 & 173 & & & & \\
\hline Corrected Total & 2116.82I & I72 & & & & \\
\hline
\end{tabular}

a. $\mathrm{R}$ Squared $=.268$ (Adjusted R Squared $=.255$ )

Source: Research Data, September, 2016.

The outcome of the ANCOVA in table 4 indicates $F(2,169)=9.386, p=0.000<0.05$, therefore, there was a statistically significant difference between the mean scores of the students in the three quasi experimental groups. The null hypothesis was therefore rejected and the alternative hypothesis was consequently accepted. Since the ANCOVA result revealed a significant difference in the achievement of the students in the three groups, a post hoc analysis was conducted to see the exact places where the differences lie among the three groups. The result of which is contained in the table below.

Table 5: Post Hoc Analysis of the Mean Scores of SIPM, SIPM with CTM and CTM Only

\begin{tabular}{llrrr}
\hline (I) Independent Variable & (J) Independent Variable & $\begin{array}{c}\text { Mean Difference } \\
\text { (I-J) }\end{array}$ & Std. Error & Sig.b \\
& & & \\
\hline I.00 SIPM & 2.00 SIPM with CTM & .778 & .582 & .183 \\
\cline { 2 - 6 } & 3.00 CTM & $2.423^{*}$ & .582 & .000 \\
\hline 2.00 SIPM with CTM & I.00 SIPM & -.778 & .582 & .183 \\
\hline
\end{tabular}




\begin{tabular}{lllll}
\hline & 3.00 CTM & $1.645^{*}$ & .545 & .003 \\
\hline 3.00 CTM & I.00 SIPM & $-2.423^{*}$ & .582 & .000 \\
\cline { 2 - 5 } & 2.00 SIPM with CTM & $-1.645^{*}$ & .545 & .003 \\
\hline
\end{tabular}

Based on estimated marginal means

* The mean difference is significant at the .05 level.

b. Adjustment for multiple comparisons: Least Significant Difference (equivalent to no adjustments).

Source: Research Data, September, 2016.

The table 5 showed that no significant difference exists between the mean scores of students in the SIPM and those in the SIPM with CTM because $\mathrm{p}$ (0.183) is greater than 0.05 level of significance. However, there is a significant difference between the mean scores of SIPM and CTM groups because the $p$ value (0.000) is less than 0.05 level of significance. This confirmed the outcome of the hypothesis test one (Hor). The mean scores of SIPM with CTM group and that of the CTM alone are also statistically significantly different because the $\mathrm{p}$ value of the relationship between them is 0.003 and this is also less than 0.05 level of significance.

\section{Discussion of Findings}

The first hypothesis test examines whether a significant difference exits in the mean scores of the three groups in their entry behaviour test (table 2). A p value of 0.317 which is greater than the 0.05 level of significance means that the three groups were equivalent or homogenous prior to the commencement of the experimental treatments. This condition is necessary in order to establish that any difference noticed between the three quasi-experimental groups after their exposure to the experimental treatments is attributed to the effectiveness of the experimental treatments and not a product of any pre-existing difference between the members of the three groups. Ferguson (2010) reported that the pretest score provided a baseline for the experimental groups so that their post test scores can be generalized for individual improvement as well as the overall class room improvement.

The second hypothesis was raised to find out whether a significant difference exists between the means of the achievement scores of the students that were exposed to the self-instructional print media and their counterparts in the conventional teaching method. The result of the t-test showed a sig. (2-tailed) value of 0.000 which is less than the 0.005 level of significance (table 3), this implies that a significance difference exits between the achievements in physics of the two groups. The meaning of this is that, the students that were exposed to the self-instructional print media outperformed those that were taught through the conventional teaching method. This is contrary to the outcome of the work of Suman and Neelam (20I3) which revealed that no significant difference existed in the achievements of the students that were exposed to the computer assisted instruction and those that were taken through the conventional teaching method in method of teaching English Language.

The last hypothesis sought to establish whether a significant difference exits among the means of the achievement scores of the three groups (table 4). The outcome of the ANCOVA test revealed a p value of 0.000 which is less than the 0.05 level of significance. This means that, though, conventional teaching method may still be useful in the teaching and learning of physics, self-instructional print media (whether used independently or collectively with the conventional teacher method) might guarantee greater improvement on students' achievement in physics. This perhaps, may be due to the fact that the students in the self-instructional print media were more actively and deeply involved in the learning process than their counterparts in the remaining two groups as observed during the field work. A likely cause of this may be as a result of the fact that selfinstructional print media presented individual student with the opportunity to make conscious and deliberate attempt at learning. On the contrary, Jadav (2014) reported that there was no significant difference in the performance of students that were taken through the self-instructional material and their colleagues that were taught in the conventional way in higher education physics.

\section{Recommendations}

The following recommendations are made based on the findings of this study.

- Secondary school physics teachers are admonished to embrace the use of self-instructional print media for effective teaching and learning in physics; this self-instructional print media can be used autonomously or conjointly with the conventional teaching method.

- Despite that the outcome of the study favours the use of self-instructional print media, physics teachers are still encouraged not to totally abandon the conventional teaching method.

\section{I0. Implications for the Stakeholders.}

The outcome of this study reveals that self-instructional print media is very effective in the teaching and learning of physics whether used independently or conjointly with the conventional teaching method. This poses a serious challenge to all 
educational stakeholders (especially the school administrators and physics teachers) on the need to modernise the teaching methodology in physics by embracing the use of self-instructional print media in teaching and learning of physics with a view to ensuring greater improvement on the academic performance of the students in physics.

\section{Limitations of the study}

The following are the factors that may constitute limitations to the outcome of this study.

- The financial expenses associated with this study constituted serious limitation to this study. A lot of money was required for the production of the self-instructional print media, transportation and logistics, payment of stipends to the research assistants, etc. Consequently, the researcher was forced to limit the number of school selected for the study to six schools (two from each district) instead of using more schools which would have improved the quality of the outcome of this study.

- Another identified limitation is the use of intact classes (non-randomized quasi-experimental groups) which make it difficult for the researcher to completely cater for the diversity among the students in each of the groups due to the confounding variables such as: intellectual ability, rate of assimilation, pace of learning, preferred learning styles etc. which may limit the generalizability of the outcome of this study.

- The study was carried out within the secondary schools in osun state. If it had been extended to other schools across the nation, the extent to which its outcome can be generalized would have been increased.

\section{Conclusion}

Self-instructional print media aided secondary school students' achievement in physics whether used autonomously or collectively with the conventional teaching method. The conventional teaching method also has positive influence on secondary school students' achievement in physics. However, self-instructional print media contributes more to the secondary school students' achievement in physics than the conventional teaching method.

\section{References}

Abida, K. and Muhammad, A. (2012). Constructivist Vs Traditional: Effective Instructional Approach in Teacher Education. International Journal of Humanities and Social Sciences,2(5).

Adani, A., Eskay, M. and Onu, V. (2012). Effect of Self-Instructional Strategy on the Achievement in Algebra of Students with Learning Difficulty in Mathematics. Us China Education Review, I006-I02I.

Adedayo, J. O. (2008). Effect of Electronic Artisan's Background and Competence in Science and Technology Advancement in Nigeria. Research in Curriculum Studies. 5(I). I32-136.

Agun, I. and Imoge, I. (Eds.). Fundamentals of Educational Technology. Ibadan; Y-Books, A Division of Associated Book Makers Nigeria Limited.

Ajayi, P. O. (2013). Comparative Analysis of the Intended and the Achieved Senior Secondary School Physics Curriculum in Nigeria.

Alena, L. and Marina, D. (2012). Problem-Based Teaching vs. Programmed Teaching: Challenges for the Future of Education. International Conference. The Future of Education. $2^{\text {nd }}$ Edition.

Anderson, T. and Fretzin, L. (2004). Programmed Instruction. http://Irs.ed.uiuc.edu/students/fretzin/eplIq2programmed.htm

Annett, J. (1964). The Role of Knowledge of Result in Learning. A survey. In Educational Technology Dececco (ed.), Holt, Rinehart \& Winston. 279-285.

Asoko, H. (2000). Learning to Teach Science in the Primary School. Improving Science Education. Buckingham; Open University Press, 5, 79-93.

Bert, Y. Kersh. (1965). Programming Classroom Instruction. In Rober Glaser (ed.), Teaching Machine and Programmed Learning II. Washington, D. C.; National Education Association, 1965.

Christopher, P. (2015). Instructional Design Models and Theories: Communication Theory .Retrieved from: https://www.elearningindustry.com/subjects/elearning concepts/instructional-design

Crowder, N. A. (1967). Automatic Tutoring by Intrinsic Programming. In Galanter E. H. (ed.). Automatic Teaching; the State of the Art. New York; Willey. I09-II6.

Curti, Merle (1935). The Social Ideal of American Educators. Pp 459-98

Dale, S. H. (2012). Learning Theories. An Educational Perspective. Boston; Allyn and Bacon

Deborah, A. S. (1997; 2004). Self-regulated Learning during Non-Linear Self-Instruction in Educational Psychology. Michigan; Michigan State University.

Emovo, E. U. (1985). Sciencing. The Nigerian Experience. The practice of Science in Nigeria. 26 ${ }^{\text {th }}$ Annual Conference Proceedings of STAN. 
Federal Republic of Nigeria, National Policy on Education. Yaba, Lagos; the National Educational Research and Development Council (NERDC) Press, 2004, Fourth Edition.

Feldman, M. A., Case, L. and Ducharme, J. M. (1999). Using Self-Instructional Pictorial Manuals to Teach Child-Care Skills to Mothers with Intellectual Disabilities.BEHAVIOR MODIFICATION,23(3),480-497. Retrieved from https://journals.sagepub.com/doi/abs/I0.I I77/0I45445599233007

Ferguson, K. (2010). Inquiry Based Mathematics Instruction versus Traditional Mathematics Instruction: The Effect on Students' Understanding and Comprehension in an Eight Grade Pre-Algebra Classroom. Master of Education Thesis \& Report. Cedarville University.

Henning, P. (1998). Everyday Cognition and Situated Learning. In Jonassen, D. (Ed.),

Handbook of Research on Educational Communication and Technology. (2 $2^{\text {nd }}$ Ed.).New York; Simon and Schuster.

Henry, H. E. (2006). Assessing the Effectiveness of Programmed Instruction and Collaborative Peer Tutoring in Teaching Java. International Journal of Information and Communication Technology Education. 2(2).

Hilgard, E. R. (1966). Learning \& the Technology of Instruction. In Hilgard E. R. and Bower

G. H. 1966. Theories of Learning. New York; Appleton-Century-Croft, $3^{\text {rd }}$ ed. P. 554-56I

Holland, J. G. and Skinner B. F. (196I). The analysis of Behaviour. New York; McGraw Hill. https://en.m.wikipedia.org/wiki/Science

Huit, W. \& Hummel, J. (1977). An Introduction to operant (instrumental) conditioning. Educational Psychology Interactive. Valdesta; Valdesta State University. Retrieved from http://www.edpsycinteractive.org/topics/behavior/operant.html

Ivowi, UMO (1982). Evaluation of Students Achievement in CESAC Science Subjects. CESAC occasional Papers No. 3, DeSunshine International Publishing Company,Lagos.

Jadav, R. M. (20I4). A study of the Effectiveness of Self-Instructional Material for Higher Education. Research HubInternational Multidisciplinary Research Journal.I(5). Retrieved from: https://www.slideshare.net/.../a-study-of-t...

Jaehnig, W. and Miller, M. L. (2007). Feedback Types in Programmed Instruction: A Systematic Review. The Psychological Record, 57, 219-232.

Jegede, S. A. and Adedayo, J. O. (2013). Enriching Physics Education in Nigeria towards Enhancing a Sustainable Technological Development. Greener Journal of Educational Research. 3(2), PP. 080-084.

Labo-Popoola Q. T. A. (2005). "Effect of Computer Assisted Instruction (CAI) and Class Size on Learners' Interaction and Acquisition of Problem Solving Skills in Physics.Unpublished Project Report: Master Degree in Educational Technology, Obafemi Awolowo University, Ile-Ife.

Laurie, M. Brown (2016). Physics: Science. Encyclopedia Britannica. Retrieved from https://www.britannica.com/contributor/Laurie-M-Brown/393

Leith, G. O. M. (1966). Survey of Programmed Techniques. Visual Education Year Book. NCAVAE.

Lewis, Roger (198I). How to Write Self-Study Material, Council for Educational Technology, Cambridge.

Lockee, B. B. Moore, D. M. \& Burton J. K. (200I). Old Concern with New Distance Education Research. Educause Quarterly, $24,60-62$.

Lockwood, F. (1997). Developing Self-Instructional Material for Open, Distance and Flexible Learning. Pre ICDE Conference Workshop Report, Pennslyvania State University.

Lord, Thomas R. (1999). A Comparison between Traditional and Constructivist Teaching in Environmental Science. Journal of Environmental Education. Vol. 30, No. 3: 22-28.

Lumsdaine, A. A. (1963). Instrument and Media of Instruction. In N. L. Gage (ed.).

Handbook of Research on Teaching. Chicago; AERA and Rand McNally. 583-682

Marguilies, S. \& Eigen L. D. (196I). Applied Programmed Instruction. New York; Willey.

Markel, S. M. (1969). Good Frames and Bad: a grammar of frame writing. $2^{\text {nd }}$ ed. New York. Wiley. Chapter I \& 4.

Martin, B. and Eugenio, E. (1992). Study in Philosophy for Children Harry Stottlemeirer's Discovery. Edited by Ann Margaret Sharp and Ronald F. Reed (1992). Temple University Press. Chapter 8, pp. 64-78.

McLeod, S. A. (2015). Skinner-Operant Conditioning. Retrieved from: www.simplypsychology.org/operant-conditioning.html

Medler, David A. (1998). A brief History of Connectionism. Neural Computing Survey, I(2), p. 18-72.

National Open University of Nigeria (2009). Advanced Psychology of Learning. Lagos, National Open University of Nigeria Press

National Teachers' Institute (2007). General Principles and Methods in Education. Kaduna, National Teachers' Institute. Page 97.

Nelkon, M. (1997). Principle of Physics. Lagos; CSS Bookshops and Hart-Davis Educational Limited. P. I-5.

Nuhu O.Y. (2016). Open and Distance Education in Relation to Socio-Economic Development. $5^{\text {th }}$ National Open University Convocation Lecture. Abuja. 
Nwafor, O. (2007). Educational Innovation: Process and Product. Enugu. Magnet Business Enterprises.

Obi, T. E. C. (200I). The Theoretical Framework of Multi-media Instructional Approach,Uyo; University of Uyo Journal of National Association of Women Academics.2 (I), 36-4I.

Ogunni, O. I. and Owolabi, O. T. (n.d.). Integration of Programmed Instruction into Mathematics and Science Teaching: A Panacea to Students Dwindling Interest in Mathematics and Science in Nigerian Schools. European Journal of Educational Research, I(3)199-209.

Ogunniyi, M. B. (1986). Secondary School Science Teaching in Africa. Ibadan, University Press Plc.

Omosewo, E. O. (1999). Relative Effect of Planned Post-Laboratory Discussion on Students' Achievement in Physics. Journal of Educational Foundations, 4(2). I6I-I2I.

Omosewo, E. O. (2012). Attitude of Teachers towards Utilizing Community Resources in Physics in Abuja, Nigeria.

Peggy, A. (2013). The difference between Classical and Operant Conditioning. Retrieved from: https://www.pinterest.com/.../...

Premack, D. (1962). Reversibility of Reinforcement relation. Science, I36, 255-257.

Premack, D. (197I). Catching up with the Common Sense or Two Sides of a Generalization: Reinforcement and Punishment. In R. Glaser (Ed.), The nature of the reinforcement. New York; Academic Press. Pp. I2I-I 50

Pressey, S. L. (1926). A simple Apparatus which gives test and score and teaches. Schools and Society. 23, 373-6

Pressey, S. L. (1927). A machine for Automatic Teaching of Drill Material. School and Society, 25 (645), 549-552.

Pressey, S. L. (1932). A third and Fourth Contribution towards the Coming of "Industrial Revolution" in Education. School and Society. 36 (934), 668-672.

Quasim, S., Imtiaz, Z. and Alvi, U. (20I4). Review of True Experimental Research Studies in Applied Linguistic. Research on Humanities and Social Science, 4,(22).

Reed, F. D. and Lovett, B. J. (2008). Views on the Efficacy and Ethics of Punishment: Result from the National Survey. International Journal of Behavioural Consultation and Therapy. 4(I),6I-67.

Richard, C. (2015). Connectionism (Edward Thorndike). Retrieved from: https://instructionaldesign.org/theories/connectionism.html

Rowntree, D. (1966). Basically Branching. London, Kogan Page, $2^{\text {nd }} \mathrm{ed}$.

Rowntree, D. (1986). Teaching through Self-Instruction; How to Develop Open Learning Material London; Kogan Page. $2^{\text {nd }}$ ed.

Rowntree, D. (1994). Preparing Material for Open, Distance and Flexible Learning: An action Guide for Teachers and Trainers. London; Kogan Page.

Sadeghi, R., Sedaghat, M. M. and Ahmadi, F. S. (2014). Comparison of the Effect of Lecture and Blended Teaching Methods on Students' Learning and Satisfaction. J Adv Med Educ Prof, 2(4).

Sadowski, K. (20I2). The Difference between Positive and Negative Punishment. Retrieved from: http://nspt4kids.com/parenting/the-difference-between-positive-and-negative punishment/

Sansanwal, D. N. (1978). "An Experimental Study in Programmed Learning for Teaching Research Methodology at M.Ed. Level”. Unpublished Ph.D. Thesis, M. S. University, Baroda.

Sara Mae Sincero (20II). Operant Conditioning. Retrieved from Explorable.com: https://explorable.com/operantconditioning

Schultz, W. (2006). Behavioural Theories and Neurophysiology of Reward. Annual Review of Psychology. 57, $87-\mathrm{I} 15$.

Shaik, F. (20I3). Thinking of Programmed Instructional Design: Need of Today's Learner. International Journal of Modern Engineering Research .3(2), I056-1060.

Sharma, A. and Sansanwal, D. N. (2002). Comparison among Video-based Instructional Strategies for Teaching Science at Class IX Level in Terms of Achievement. Indian Educational Abstract, NCERT, Vol. 3. No I, P. 3I-32.

Sharma, Hermant L. "Development of Self-Instructional Print Material for Distance Education Learners (M.Ed.) in Statistics”. Unpublished Project Report: Diploma in Distance Education, IGNOU, New Delhi.

Skinner, B. F. (1938). The Behaviour of Organism: An experimental analysis. New York, Appleton-Century.

Skinner, B. F. (1948). Superstition in the Pigeon. Journal of Experimental Psychology, 38, I69-172

Skinner, B. F. (I95I). How to Teach Animals; Freeman

Skinner, B. F. (1958). Teaching Maching. Science, I28 (3330), 969-977.

Skinner, B.F. (1953). Science and Human Behaviour. New York; Simon and Schuster .com

Stroud, K. A. (200I), Engineering Mathematics, London; Palgrave.

Suman, C. and Neelam, D. (2013). Comparative Study of Computer Assisted Instruction Technique (CAI) on the Achievement of Pupil Teachers in Methods of Teaching English Language. MIER Journal of Educational Studies, Trends and Practices,3(I),07-II8.

Sushma, T. (20I4). Comparative Effectiveness of Computer Assisted Instruction (CAI) with Traditional Instruction at the Teacher Training Level. International Journal of Research, I(9). 
The New Encyclopedia Britannica, 2014. Science. Retrieved from: https://www.britannica.com/topic/science

Thorndike, E. et al. (1928). Adult Learning. New York; Macmillan.

Thorndike, E. L. (I905). The Element of Psychology. New York; A. G. Seiler.

Thorndike, E. L. (I9II). Animal Intelligence. New York; Macmillan

Thorndike, E. L. (I9I2). Education: A First Book. New York; The Macmillan Company.

Thorndike, E. L. (I9I3). The Psychology of Learning. New York; Teachers College Press.

Thorndike, E. L. (I92I). The Teachers Workbook. New York; Teachers College Press.

Thorndike, E. L. (I922). The Psychology of Arithmetic. New York; Techers College Press.

Thorndike, E. L. (1932). The Fundamentals of Learning. New York; Teachers College Press.

Udo, M. E. (20II). Effect of Problem Solving, Guided-Discovery and Expository Teaching Strategy on Students' Performance in Redox Reaction. African Strategy Review,5(4). Retrieved from www.ajol.info/index.php/afrrev/article/view/69279

Unwin, D. (1967). The Changing Concept of Programmed Material Criterial for Categorization. In Tobin M. J. (ed.). Problems and Methods in Programmed Learning I. National Centre for Programmed Learning , Birmingham.

Weilbell, E. L. (20II). Principles of learning: 7 Principles to guide personalized, student centered learning in the technologyenhanced, blended learning environment. Retrieved from https://principlesoflearning.wordpress.com

Yusuf, M. O. and Afolabi, A. O. (20I0). Effect of Computer Assisted Instruction (CAI) on Secondary School Students' Performance in Biology. Turkish Online Journal of Educational Technology,9(I),62-69.

\section{Copyrights}

Copyright for this article is retained by the author(s), with first publication rights granted to the journal. This is an open-access article distributed under the terms and conditions of the Creative Commons Attribution license (http://creativecommons.org/licenses/by/4.0/). 